\title{
Methods and Strategies for Cultivating "Craftsman Spirit" of Landscape Architecture Students
}

\author{
Zhu Qiandao1, Yu Yan² \\ ${ }^{1}$ Guangdong AIB Polytechnic College, Guangzhou 510507, Guangdong, Peoples R China. \\ ${ }^{2}$ Guangzhou Maritime Institute, Guangzhou 510725, Guangdong, Peoples R China.
}

\section{Keywords: Landscape Architecture; Students; Craftsman Spirit}

\begin{abstract}
Firstly, this paper expounds the concrete methods of cultivating the "craftsman spirit" of landscape architecture students, including the cultivation of "craftsman spirit" of landscape architecture students in colleges and universities and the combination of theory and practice in cultivating "craftsman spirit" of landscape architecture students. Secondly, it analyzes in detail the important role of cultivating the "craftsman spirit" of landscape architecture students, including further promoting the cultural construction of colleges and universities and further developing the quality education of students majoring in landscape architecture. Finally, it deeply analyzes the practical significance of cultivating the spirit of craftsman among college students majoring in landscape architecture, including conveying a large number of landscape architecture professionals to the society and meeting the needs of students' career development, so as to make relevant people in college landscape architecture realize the importance of the "craftsman spirit".
\end{abstract}

\section{Introduction}

At this stage, people's living standards are gradually improved, and the awareness of protecting the ecological environment is gradually enhanced. In the urban construction of our country, landscaping has been paid attention to. With the continuous development and construction of the city, the environmental pollution is becoming more and more serious. Through the construction of landscaping, the noise can be slowed down. With the increase of social demand for garden professionals, there are new requirements for the cultivation of garden professionals in colleges and universities. Students majoring in landscape architecture should learn and apply the "craftsman spirit" while studying the relevant professional knowledge of landscape architecture comprehensively and systematically. This spirit can help students majoring in landscape architecture to better invest in landscape architecture in the future, realize the sustainable development of landscape architecture and realize the inheritance of "craftsman spirit".

\section{Specific Methods to Cultivate "Craftsman Spirit" of Landscape Architecture Students}

\subsection{Cultivation of "Craftsman Spirit" of College Landscape Architecture Students}

Our country's university landscape architecture specialty provides more professional talents for the society, enabling students to apply the professional knowledge learned in the campus to social practice. In order to better cultivate the students' spirit of craftsman, the relevant guidance teachers must proceed from the requirements of the internal laws of professional education for classroom teaching and practical guidance.

In social practice, for example, in the process of landscaping, students understand that after transplanting trees, in order to enable their roots to penetrate deep into the soil, it is necessary to irrigate once, which can promote the development of plant roots. Then follow-up watering should be carried out according to different growth conditions of root plants to ensure that watering is carried out at the right "time" and that each watering must be thorough. Generally speaking, in order to make plants grow healthily and healthily, the first fertilization is mostly in the first autumn after transplantation, and the second fertilization is mostly in the second spring. In this way, the trees can maintain humidity in cold winter, and at the same time, the evaporation of the moisture party can be 
effectively inhibited. In the process of practice, students combine the garden-related knowledge learned in class with practice, and deal with unexpected problems in a timely manner.

\subsection{To Cultivate the "Craftsman Spirit" of Landscape Architecture Students, Attention Should be Paid to the Combination of Theory and Practice}

The cultivation of "craftsman spirit" for college students majoring in landscape architecture is the key and difficult point in teaching. College leaders and guidance teachers need to improve their teaching and training modes, and need to adjust teaching strategies at any time in the whole process of education and teaching to ensure that students' professional skills and professional spirit meet expectations. Professional skills determine students' mastery of professional knowledge, and professional spirit is "craftsman spirit". The traditional form of "full house irrigation" education can no longer meet the needs. Only by breaking the shackles of the traditional education mode, redefining the teaching methods and improving the teaching objectives, and having a correct understanding of the value of garden technology education, can the "craftsman spirit" of garden students be better cultivated.

\section{The Important Role of Cultivating "Craftsman Spirit" of Landscape Architecture Students}

\subsection{Promoting the Cultural Construction of Colleges and Universities}

Cultivating the "craftsman spirit" of landscape architecture students can effectively promote the cultural construction of colleges and universities. At the NPC and CPPCC in 2016, the "craftsman spirit" appeared in the government work report, advocating that the "craftsman spirit" should be glorified in the whole society and that the "craftsman spirit" should become the common spiritual pursuit of workers. Most colleges and universities in our country have rich cultural accumulation and inheritance, and pay more attention to the renovation of campus environment. The core and key point of the education of landscape architecture in colleges and universities is the education of craftsmen spirit. The construction of campus culture in colleges and universities needs to optimize the construction of the original cultural sites in order to provide a better learning environment for students majoring in landscape architecture, to further improve the level of craftsman spiritual education for students majoring in landscape architecture, to make the construction of college culture better, and to enhance the ideological level of students.

\subsection{Quality Education for College Students Majoring in Landscape Architecture Technology Further Developed}

At this stage, it is an important goal to cultivate students' craftsmanship spirit in garden teaching in our country's colleges and universities. At the same time, it can also reflect students' learning results intuitively. With the development of society, colleges and universities pay more attention to the cultivation of the spirit of craftsmen. Most colleges and universities have extremely rich resources for the education of the craftsmen spirit. The core and focus of education in colleges and universities across the country is quality education. These abundant educational resources will naturally provide very powerful conditions for their development in quality education. In other words, the prerequisite for the effective development of quality education is rich educational resources. At the present stage, the major "goal" of teaching in our country's colleges and universities is quality education. In order to realize this teaching goal, it is necessary to continuously inject the co-construction of spiritual education resources, so as to provide a good education environment with craftsmanship spirit for landscape architecture students. 


\section{The Practical Significance of Cultivating the "Craftsmen Spirit" a mong College Students Majoring in Landscape Architecture}

\subsection{Transport a large number of landscape architecture professionals for the society}

Judging from the scope of division, the category of professional spirit includes "craftsman spirit". The so-called "craftsman spirit" means that the "craftsman" focuses on sticking to the brand, continuously improving skills, further improving quality, being unique in product ingenuity and being awed by the profession. At this stage, our country is still in a period of economic transformation, and the demand for professional talents is increasing gradually, which requires colleges and universities to pay more attention to the cultivation of students' professional knowledge and practical ability. In order to train students majoring in landscape architecture into excellent landscape engineers, colleges and universities need to pay more attention to the education of "craftsman spirit". This requires colleges and universities to integrate craftsman spirit into innovative education, so that students can gradually form correct values, develop good professional spirit, and transport more professional talents for the relevant industries of social garden demand during the study period of landscape architecture.

\subsection{Meeting the Needs of Students' Career Development}

The "craftsman spirit" of garden workers in garden-related industries will play a decisive role in the future career development. Generally speaking, employees with craftsman spirit will play a greater role in the future development of the enterprise, and the enterprise will also cultivate them. Generally speaking, when an enterprise recruits talents, when the applicant has one or more skills, he is a conscientious and responsible person who is able to work hard and complex, down-to-earth, and of course this is another manifestation of craftsman spirit. Therefore, our country's colleges and universities continuously strengthen the cultivation of craftsman spirit in order to significantly improve the matching rate and employment rate of students and lay a foundation for students to base themselves on society.

Concluding remarks: The cultivation of students majoring in landscape architecture in colleges and universities transports talents for the relevant industries of social landscape architecture, and the untiring pursuit of self-value is called "craftsman spirit". As a college that trains landscape architecture professionals, it must shoulder the burden of training students' craftsman spirit. At the same time, colleges and universities need to optimize this as a mode of theoretical teaching and practical teaching, increase school-enterprise cooperation, and strive to train more outstanding talents with "craftsman spirit" that are beneficial to society, garden construction and environment improvement, to transfer more garden professionals with solid theoretical knowledge, strong practical ability and protection of ecological environment development to society, and to make greater contributions to the sustainable development of garden greening.

\section{Acknowledgment}

Subject name: Research on the Methods and Strategies of Cultivating "Craftsman Spirit" of Garden Technology Major Students in Higher Vocational Colleges

Project Source: General subject of Guangdong Provincial higher Vocational and Technical Education Research Association in 2016

\section{References}

[1] Zhao Yazhou, Zhang Yan, He Xiangfeng, Leng Pingsheng.Exploration on Teaching Reform of "Landscape Ecology" Course for Landscape Architecture Major[J]. Forestry Education In China,2019(04):39-43.

[2] Wu Hao, Gao Jianli.Exploration and Analysis of Cultivation Path of Craftsman Spirit for Landscape Professionals in Higher Vocational Colleges under Modern Apprenticeship 
System[J]. Think Tank Era,2019(28):68+72.

[3] Han Guang.Teaching Reform of Landscape Design Course Based on "Application-oriented" Talent Cultivation Concept[J]. Xiandai Horticulture,2019(12): 226-227.

[4] Tian Zhongping, Li Chengzhong, Luan Ling.Research on Talent Training Mode of Landscape Architecture Major in Higher Vocational Colleges Based on the Demand of Real Estate Industry under the Background of "the belt and road initiative"[J]. Vocational Technology,2019,18(05):5-8.

[5] He Yuhui, Wang Chunmei, Xu Dawei. Research on the Construction of School-enterprise Cooperation Talent Training Mode for Landscape Architecture Major[J]. Xiandai Horticulture,2018(24):198-199.

[6] Ma Weige, Zhang Wenying.Exploration and Practice on the Path of Cultivating Students' Craftsman Spirit in Garden Technology Major[J]. Xiandai Horticulture,2018 (16):224.

[7] Li Mingchao.Exploration on Cultivation Strategies of Artisans Spirit for Animation Majors in Higher Vocational Colleges[J]. Journal of Changzhou Vocational College of Technology,2018,17(01):17-20.

[8] Guo Chenjing. Strategies for Cultivating Artisans Spirit of Animation Majors in the New Era[J]. Western China Quality Education,2018,4(01):79. 